\title{
MAKUNAIMA, O MEU AVÔ EM MIM!
}

Jaider Esbell ${ }^{1}$

Revisão: Parmenio Citó

$\mathrm{Eu}$ aconteço, artisticamente falando, acredito, dentro de um processo que nos convida a pensar criticamente a decolonização, a apropriação cultural, o cristianismo, o monoteísmo, a monocultura e todos os dilemas do existir globalizado. Ou não? O meu surgimento vem junto com a expectativa que se cria em volta de outro termo, no Brasil ao menos, a arte indígena contemporânea. Não a moderna, a passada e extinta, nem a por vir, mas a deste início do século XXI. ${ }^{2}$

Adianto que não ando só, que não falo só, que não apareço só. Faço saber que toda a visualidade que me comporta, todas as pistas já expostas do meu existir são meramente um passo para mais mistérios. Somos por nós mesmos o poço de todos os mistérios. Faço saber ainda que não temos definição, que viemos de um tempo contínuo, sem estacionar. Antes, faço saber que buscamos os sentidos mais abstratos, tratamos de outros tratos bem firmes nessa passagem. Antes mesmo, devo dizer que tanto meu avô Makunaima quanto eu mesmo, parte direta dele, somos artistas da transformação.

Surgimos junto com a arte todos os desafios do grande existir e suas mais claras urgências individuais e coletivas. Surgimos no aparente caos, como é mesmo descrito entre os grandes Xamãs do mundo e um quase consenso na ciência, em termos de rumos para a humanidade tal qual. O prenúncio matemático do fim do mundo é também um cenário de nossa aparição. Como produto, também desse tempo, tenho a ideia de que a colonização foi um processo, embora saiba que trata-se de um ato contínuo.

Assim, olhei para todos os lados e vi meu o avô no horizonte. No horizonte está claro também que não haverá cultura tampouco vida - e vida de qualidade, muito menor - para quem quer que seja em nada sendo feito. Não é possível, caso não rompamos alguma membrana extra do agora, pensar uma ideia de futuro em questões de nossa ligação espiritual com a terra e com o nosso lixo. Adianto, Makunaima não é só um guerreiro forte, másculo, macho e viril distante de uma realidade possível, não senhores. Ele é uma energia densa, forte, com fonte própria como uma bananeira.

\footnotetext{
${ }^{1}$ Artista Makuxi, Roraima, Brasil

${ }^{2}$ Nota da Organizadora: Artigo original convidado especialmente para essa publicação
} 
A ideia inicial da construção deste texto me fez pensar profundamente os propósitos da ciência em fazer da arte um instrumento de estímulo ao pensamento. Visto que bem ocupo um lugar privilegiado de trabalho não me furto em deixar pistas ou acessos para que todas as questões maiores estejam contempladas. Falamos em desconstrução? Gênero, sexualidade e o extrapolar de mundos serão temas recorrentes pois fazem parte da vida e para a arte tudo é mesmo substância. Ter a liberdade na escrita não quer dizer muito quando o mundo precisa de outros meios possíveis para se traduzir em si mesmo.

Há esse agenciamento na educação escolar? São questões que nos apetecem. Empréstimos temos que fazer a todo o momento. Empréstimos que já vêm de longe descaracterizando as coisas, as energias e não queiramos nós ter a essência das coisas pois estas coisas não estão para nós a menos que elas mesmas nos sucedam.

Ensaio escrever para socializar um pouco o socializável da minha relação com meu avô, esse que não é gente exatamente para não sê-lo. Portanto Makunaima é meu avô e o gênero, a forma e o conteúdo têm seus lugares de ação como vamos citar sempre, pois são fundamentais, mas é preciso ir além. Makunaima está além e prova isso ao transformar-se continuamente. Não, ele não é transformista. Vamos dissociar aos poucos o existir-atuação de Makunaima dos efeitos cognitivos do gênero em nossas mentes. Sim, nas mentes.

Então Makunaima me aparece primeiro colonizado? Eu nem bem apresentei o meu avô e já lhe convido a ir além do gênero, além do tempo. É que vamos ter que visitar um outro mundo. Isso eu também devo lhe avisar. Devo lhe avisar que estas estórias são parte da minha vida e que realmente Makunaima é meu avô; isso é um fato. Makunaima e muitos outros vovôs são daqui do extremo norte da Amazônia. Nós temos uma história e uma geografia. Somos parentes diretos. É uma relação biológica, genética, material e uma parte substancial em espírito, ou energia.

$\mathrm{Eu}$, quando assumo e reivindico o meu laço familiar com Makunaima, estou convidando a ir ao além no discutir decolonização ou colonização. Quando tomo isso como um argumento quero dizer que é parte minha querer que em todas as partes estejam algum extrapolar dos discursos. Quando faço isso publicamente em um lugar estratégico, com arte, acredito estar sendo paradidático. Pois sou artista e enquanto pessoa aplico minha revelação, fruto de minha pesquisa, em minha vida plena sendo esta também pesquisa de minha pesquisa. 
Um sentido para a existência da Pan-Amazônia e seus povos passa nas mãos de Makunaima. Existe, onde me empenho em levar, um pleno sentido para além dos factoides sobre a preguiça e a falta de caráter do Makunaima.

De fato nem quero falar destas questões, embora tenham sido elas que nos trouxeram para este ponto. Existe todo um entremeio não de explicação, mas de possibilidade de entendimento. Sem adentrar as portas das cosmovisões dos povos originários não há como discutir decolonização. Sem considerar as culturas mexidas e hoje abertas para a discussão com parte humana representada não há como discutir fronteira alguma.

Desde antes das anotações de Theodor Koch-Grünberg ${ }^{3}$ até o caso de Makunaíma estar na capa do livro $^{4}$ e ganhar o mundo também com o cinema, ${ }^{5}$ caminhos para a decolonização podem ter sido deixados.

Acredito que haja outro momento para além do oriente e ocidente se juntando para tentar encapsular o pensamento. Ganham novas dimensões quando velhos termos são postos em outros contextos. O caso é que vivemos em estado de arte e o passeio em outros mundos é apenas uma forma de como podemos pensar e experimentar a tão falada decolonização.

Makunaima e decolonização soam termos soltos no meio da multidão, ou seja, o povo, aquele a quem nós midiáticos buscamos. Ou não? Acontece que Makunaima expôs-se em Makunaíma para ser parte da cultura disponível. Uma vida inteira a esse propósito é anunciada para a contextualização mínima. A minha relação com meu avô será o nosso passeio. Makunaima no círculo que este texto alcança é, ou poderia ser, minimamente conhecido por sua parte exposta antes na arte, no mundo.

Tanto quanto outros ou todos os atores fantásticos colonizados com nossa gente Makunaima deve ser retirado da ala dos folclores. Significativamente, Makunaima é envolvido nas leituras que são propostas por diversos influentes sobre o caráter duvidoso do brasileiro. Isso está relacionado também com a Semana de Arte Moderna de 1922,

\footnotetext{
${ }^{3}$ Nota da Organizadora: Etnólogo alemão (1872-1924), pesquisador vinculado ao Museu de Etnologia de Berlim. Suas pesquisas no Brasil incluem o estudo da mitologia e etnologia de povos amazônicos. Vom Roraima zum Orinoco (1917) é fonte referida por Mário de Andrade na obra literária e modernista Macunaíma: o herói sem nenhum caráter (1928).

${ }^{4}$ Nota da Organizadora: Apenas quatro anos após a morte de Theodor Koch-Grünberg, e onze anos após a publicação de Vom Roraima zum Orinoco, Mário de Andrade publica em São Paulo a obra Macunaíma: o herói sem nenhum caráter, com uma tiragem independente de apenas 800 exemplares, marco do modernismo brasileiro.

${ }^{5}$ Nota da Organizadora: Macunaíma: herói sem caráter. Comédia. Brasil, 1969, 188min., COR. Direção: Miguel Joaquim Pedro de Andrade. Adaptação da obra literária de Mário de Andrade.
} 
tempo de quase um século quando surgimos com mais essa demanda. $\mathrm{O}$ hoje e o futuro dessa gente-nação de identidade desafiadora, beirando o fantástico, de onde mesmo lhe é proposto com arte. Pena Mário não estar mais aqui para ver e sentir esses outros lados dos movimentos. Mas não tem problema, suas crias, que também o sou, estão por aqui.

Makunaima sabia sempre o que fazia; parto deste pressuposto. Ele expôs-se sozinho e em estratégia. Agora é outro tempo. O tempo que ele pensou que chegaria não levou nem um século. Onde me couber, vou. Vou além de minha relação direta com ele. Como artista também dou um salto na colonização e vou antes do tempo disso tudo. Acredito e sinto que em determinado momento posso estar em um tempo anterior, em um tempo de nossas diversidades pré-colonialistas.

Aos leitores é requerido um vácuo total interior, um nudar-se por dentro para ter espaço. Em uma grande concepção, é requerido um esvaziamento total de um ser para outro ser caber. $O$ ser vem pleno e ele mesmo traz seu caber. O novo ser não fica portanto onde não the caiba pleno. Repito, não ando só, não falo só, não apareço só. Reitero, toda a visualidade que me comporta, todas as pistas já expostas do meu existir são meramente um passo para mais mistérios. Somos por nós mesmos o poço de todos os mistérios. Ressalto, não temos definição, viemos de um tempo contínuo, sem estacionar. Lembro, buscamos os sentidos mais abstratos, tratamos de outros tratos bem firmes nessa passagem. Reforço, tanto meu avô Makunaima quanto eu mesmo, parte direta dele, somos artistas da transformação.

Quando meu avô transforma algo em pedra ele não destrói. E Makunaima passa, na volta, vem transformando o que transformou na ida. Ele vem sempre em outra forma. Quando Makunaima ao caminhar na savana deu de cara com uma pedra grande, branca, não hesitou, parou diante da pedra e transformou-a em um touro. Makunaima tinha poderes e decisão para transformar a pedra em touro e assim o fez. Ao transformar a pedra em touro, o touro, ao ver Makunaima, lhe atacou. $O$ touro atacou seu criador como a uma criatura. Makunaima lutou com o touro. A luta foi brava. Por fim o touro passou a conhecer Makunaima e passou a amá-lo como seu paralelo, como algo parte de si mesmo. Ele cria as coisas com suas decisões. Tudo o que ele vê, tudo que toca, passa a receber um outro tipo de ação, um outro tipo de energia, algo que desencadeia um mover em seu ser, no ser que foi tocado.

Makunaima como disse dispensa uma forma, um gênero, uma gênese. É um estado de energia que se cria e recria em si mesmo como uma bananeira que não precisa 
de par. São as cobranças mundanas de nossos humanos sentidos que nos exigem uma referência lógica. Eis que Makunaima experimenta uma forma de materialidade, de sonoridade, de sensitividade acessível aos seus descendentes, como uma ideia de gênero, por exemplo. Ele vem então em muitos estados transitórios, passa a aparecer além da oralidade, além do mito. Desce de seu estado supremo flechado por seu orgulho superado; quando enxerga-se além de seu orgulho e depois de todo o seu sofrer essencial. Ele rompe todos os limites, subverte todos os conselhos, deixa beijada a mão do seu avô, o jabuti, e vai ao encontro do pai de todos nós, o universo.

Do universo Makunaima vê a Mãe Terra e, de lá, se entristece. Por lá Makunaima quer estar, mas a mãe lhe suplica e ele não suporta o clamor de sua mãe, e volta. Desce para encontrar sua família. Vai ao lugar de origem e vê as flores em botão. Uma dessas floradas darão grandes poetas. Eis que Makunaima vai, uma a uma, para conferir. Alegre está e ao passar perto de minha rede lhe puxo pelo dedo. Ele me vê. Seus olhos brilham e me absorvem. Fiz-me em meu avô, somos agora um só, de fato. Antes desse momento fotografia e dentro dela estamos eu e meu avô em constante movimento. Estamos em constante passagem e nossa origem comum é desconhecida para muitos, mas há o caminho vivo a que se quer chegar.

Entro em associação nesse texto como não podia ser diferente. Sou neto direto de Makunaima. É uma relação de família, algo íntimo e sagrado que só mesmo o respeito pode aproximar. Então, sou artista assim como meu avô; sou meio como o meu avô. Seguro no dedo do meu avô e vamos seguindo. Com o tempo vou crescendo e meu avô Makunaima vai diminuindo e vamos indo até ele virar criança e eu me tornar um velho e inverter a lógica da vida e da existência seguindo assim para sempre. Eis que tudo então é só o instante e logo já estará passando a outra coisa.

Essa é a nossa linguagem, um ato contínuo em si mesmo, a transformação. Lá, antes de vir o outro, a conjuntura era a conjuntura de lá. Uma origem em si mesma, um recurso próprio do grande ato, a criatividade. Surgimos com o tudo, do nada. Trouxemos a origem do mundo e foi para todos que surgimos. Surgir é uma palavra emprestada. Quando agora emprestamos tudo para desencantar. Desencantar é um estado transitório diretamente relacionado ao ato de destruir o que logo foi associado ao meu avô em sua grande jornada pelo mundo; a falta de caráter e o desdém por tudo.

Antes de um século apenas nós estamos no rastro dele, sempre. Estou aqui para resgatar meu avô, levá-lo pra casa pra cuidar dele. O ser que sou, eu mesmo, é homem, 
um guerreiro pleno de 1,68 metros, $82 \mathrm{~kg}, 39$ anos. É livre como deve ser. É livre como é meu avô Makunaima ao se lançar na capa do livro do Mário de Andrade. Ele se deixou ir; foi o que me disse em uma de nossas inúmeras conversas de avô e neto. Assim me diz ele:

\begin{abstract}
Meu filho eu me grudei na capa daquele livro. Dizem que fui raptado, que fui lesado, roubado, injustiçado, que fui traído, enganado. Dizem que fui besta. Não! Fui eu mesmo que quis ir na capa daquele livro. Fui eu que quis acompanhar aqueles homens. Fui eu que quis ir fazer a nossa história. Vi ali todas as chances para a nossa eternidade. Vi ali toda a chance possível para que um dia vocês pudessem estar aqui junto com todos. Agora vocês estão juntos com todos eles e somos de fato uma carência de unidade. Vi vocês no futuro. Vi e me lancei. Me lancei dormente, do transe da força da decisão, da cegueira de lucidez, do coração explodido da grande paixão. Estive na margem de todas as margens, cheguei onde nunca antes nenhum de nós esteve. Não estive lá por acaso. Fui posto lá para nos trazer até aqui.
\end{abstract}

Foi o meu avô que contou tudo isso pra mim. Ele não tem segredo nenhum comigo e foi mesmo ele que mandou lhes falar. Foi mesmo ele que me autorizou a citálo, a reivindicá-lo, a cultivá-lo, vivê-lo, ressuscitá-lo.

Minha relação com meu avô Makunaima é muito forte por meio da arte e por meio do sangue. Sim, temos o mesmo sangue, a mesma astúcia, o mesmo caráter. Eis o grande artista Makunaima, o grande ser incompreendido. Eu mal nasci e fui alçado pelos pés com o pulo que meu avô deu para me alcançar.

Ele me disse:

- É você mesmo. É você que eu esperava para me acompanhar.

Então me mostrou o caminho. Mas eu era apenas uma criança e não sabia de fato o tamanho do meu avô, que logo me levou escanchado no ombro a cruzar os primeiros montes. Foi assim a minha introdução no mundo, meu avô foi me mostrando.

Só nesta vida já são mais de trinta anos de um caminhar diário em sua própria origem e trajetória. Meu avô me contou que provou a fruta proibida. Me contou que a fruta proibida nada mais é que a coragem. Me disse que o exemplo maior para nosso entendimento contemporâneo foi lançar-se na capa do livro. Quando Makunaima decide lançar-se na capa do livro sabia o que estava fazendo. Meu avô sempre sabia o que estava fazendo. Não tinha escolha, era sua vida a acontecer. Makunaima deu o grande salto, comeu inteira a fruta proibida. Quando Makunaima decide expor-se faz estremecer o universo, algo novo realmente surge, algo urge latente no universo. Nada mais seria como antes, a decisão estava tomada.

Quando, de outro tempo, Makunaima precisa expor evidências de suas decisões universais, nos conta sobre o corte da grande árvore Wazak'á. Sim, outro ato grandioso, 
determinante para a pan-origem de todos seus filhos; e é dele a decisão. Ele cortou a grande árvore para o existir de todos esses que se espalham na vastidão da verde floresta de hoje. Cortou a árvore para dar vida também aos habitantes da savana, aqui nesta parte do mundo. Havia fome, escassez, quando a natureza mostrou para Makunaima e seus irmãos as grandes árvores. Foi o Deus maior, que é a Natureza maior, que por meio da cutia mostrou a Makunaima a grande árvore de todas as frutas e sementes. Não, não era apenas uma, mas, simbolicamente, ficamos com a maior, a mais imponente, a primeira.

A árvore do bem, que ao tombar levou ao chão também a árvore dos mistérios, a árvore dos outros seres, a árvore proibida que ainda hoje existe o tronco ao lado da árvore da vida derrubada por Makunaima. A natureza deixa, portanto, Makunaima diante da grande árvore. Deixa ele lá com o pescoço virado para cima vendo e analisando se vai mesmo tomar a grande decisão. Makunaima está parado medindo seu existir. Com o machado na mão toca o tronco da árvore e recebe um choque. É um sinal para o corte. Ele teria a coragem. Makunaima dá os primeiros golpes e então seus irmãos convencidos do ato seguinte o ajudam na jornada. Depois de muito tempo a grande árvore vem ao chão e o mundo se recria, se re-transforma ainda mais.

$\mathrm{O}$ ato glorioso e transgressor de derrubar a árvore encantada é só mais um momento, mais uma decisão, uma atitude universal. É preciso fatiar o tempo para o mínimo entendimento. É preciso ouvir o silêncio-pensamento de Makunaima entre uma machadada e outra. Não era o mero ato de cortar; era por a vida em outra dimensão. Em todas as passagens que me conta meu avô sobre seu lançar-se sobre a vida é nesse sentido. $\mathrm{O}$ estar diante da possibilidade e o ato seguinte vêm com a grande decisão.

Quando Makunaima decide estar na capa do livro, sabia que a partir daquele momento sua vida ganharia outra dimensão. Sabia da grandiosidade do ato dessa representação de realidades ainda a vir a se extrapolar. Sabia da importância dos ícones na cultura que havia chegado. Sabia dos limites e da gana daquele povo. Sabia da sua missão e foi. Foi para o livro, foi para o cinema, foi sujeito e entregue para o mundo. Foi por saber, por lucidez, foi por querer. Sabia que estar na capa do livro era estar em um outro ambiente. Sabia que em um mundo carente de deuses e bondades sua imagem estaria sendo associada a algo ainda não vivido, mas bem conhecido. Sabia de tudo, sabia de todas as etapas sentidas até seu pleno fazer que é o agora.

O endeusamento de Makunaima lhe permite viver ainda mais as amarguras necessárias para o triunfo que virá. O herói sem nenhum caráter estava pronto para abrir 
os braços bem abertos ao mundo e receber sua chuva de flechas, suas estocadas contínuas e esse projetar nos indígenas por todo o existir. Nos preservou se entregando, se fazendo caça ao caçador. O surgimento, o encantamento, a máxima sucção e o abandono de meu avô como um inútil trapaceiro chega ao fim aparentemente. O martírio, algo de mártir é sentido na vida de Makunaima, é mais sabedoria e prazer absoluto de um outro tipo de amor; não por ele.

Makunaima é um ser pleno de coragem. Aparece humanizado. É tido como homem e em parte da aparição é visto como sem qualquer compromisso com a vida e com o amor. É mostrado seco, mal, do tipo perverso, detentor de péssimas qualidades, mesmo como um reforço à ideia de machismo e patriarcado. E foi exatamente o que aconteceu, ao estar alçado ao topo da visibilidade meu pequeno avô vai ao encontro do trovão, vai ao centro do fogo e chega mesmo a tomar chá com Deuses e Demônios. Makunaima foi ser sua jornada.

A máxima exposição de Makunaima reflete severamente para dentro da floresta a ideia leviana de um tipo curioso de monoteísmo. Vieram os ismos, o cristianismo especialmente. Reflexos de todos os tons de existência incidem em Makunaima que os recebe com contra-reflexos. Seria Makunaima o grande Deus, o maior e mais perverso, pois foi essa a tentativa imperativa de extrair-impondo por força tal identidade. Foi essa a proposta enviesada, que tanto se festejou, esse fracasso de sentimento que é a cara falida da cultura brasileira. Foi um fracasso humano, uma leitura mundana sem profundidade.

Em lugar nenhum pode caber o não tem alma para caber. Não tem substância para caber os dilúvios de Makunaima em mais uma vez desconstruir e construir. É função atual de Makunaima, em sua nova vida, desmentir. É papel de Makunaima pelo poder que lhe foi atribuído, devolver. Devolver as visões que sua aura, luz super poderosa, roubou por encantamento.

Meu avô vai devolver tudo; vai devolver o porquê de todas as histórias, a simplicidade da vida. Makunaima vai tirar de si os olhos penosos do mundo e direcionálos para a natureza. Makunaima se volta em guerreiro do inconformismo como unicamente é e vai mostrar aos donos de cada coisa a alma-espírito de cada coisa. Voltamos a entrar pelas mesmas portas abertas, as veias abertas no mundo dos desconhecidos. Mais curiosidade para chamar à memória, mais movimento para ir além. Mais um tempo para novos olhares. Mais política e tecnologia, mais magia e outros espetáculos. 
Vivemos em estado de arte e assumimos isso. Viemos de outras estruturas para nos fazer cabíveis aqui nessa ideia de tempo. Os caminhos deixados por meu avô se abrem para outros passeios, tempos de outras festas. Onde ele foi posto em desuso é o nosso destino ir além mostrando novas frestas. Devo acompanhá-lo em seu revisitar, atravessar de volta de onde fui alcançado para reaprender. Ouvir a vida no caminhar de meu avô e traduzir, vivendo como ele quiser e o que ele quiser, na dimensão que me couber. Estaremos em tom de universo, cor de terra verde de floresta em arte em seu estado máximo de fluidez.

Todas as visões são transitórias e há mais de um em mim. Nunca haverá uma conclusão e minha passagem é tão temporária como essas aparentes demandas e suas urgências. Relembrar detalhes essenciais são fundamentais, portanto. $\mathrm{O}$ fato que saímos recentemente da plena oralidade, de um mundo mais de sentimento que de sentidos literais, pesa muito nessa equação. $O$ fato de vivermos em estado de colonização permanente também tem seu fator obrigador a nos motivar a estar em uma além das coisas. Caminhamos abertos junto com os grandes temas do mundo, a fé, a educação, a cultura, o gênero. E também acreditamos por nossa natureza fortemente espiritual que nossa arte pode dar alcances. Alcances outros como a nós foi dado muito ou tão pouco tal qual seja ao menos compor ativamente a grande diversidade para sempre. 


\section{Imagem, mito, arte e contextos}

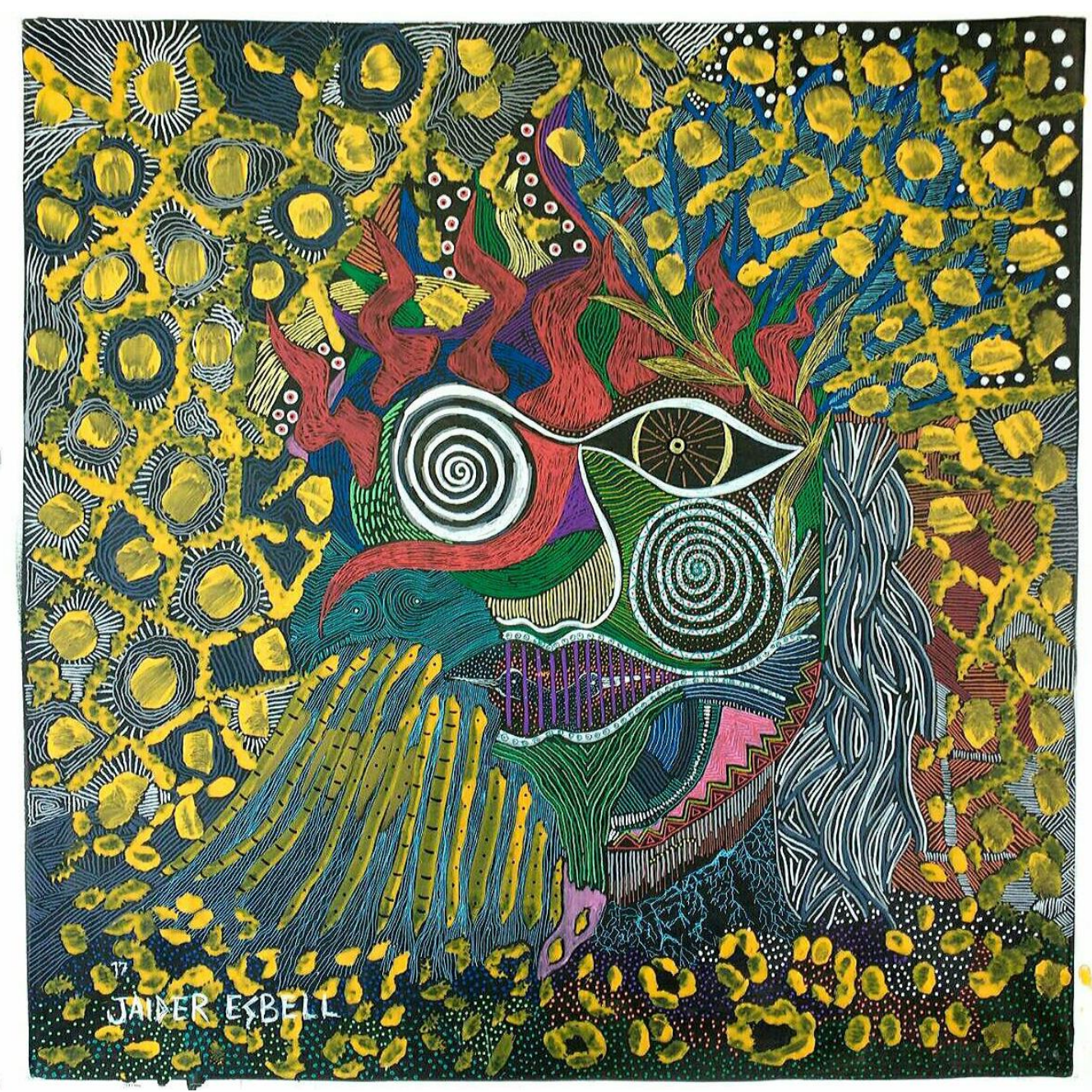

Makunaima - I. Técnica: acrílica e pincel posca sobre tela. Tamanho 90 x 90 cm. Ano 2017.

A obra faz parte da coleção Meu avô Makunaima, proposta de exposição contextual em auto curadoria que exponho em Manaus, no ano de 2018, no coração da Amazônia.

A imagem sugere um agregar de elementos dispersos para o surgimento de uma ideia figurativa para o mito fluido.

É fluido pois vem de um estado de energia e caminha por um tempo onde em um determinado espaço desse tempo homens e demais seres também eram mais fluidos.

Fundiam-se? 
Vamos anotar essas questões para o momento.

Falamos aqui do tempo em que tudo poderia ser tudo.

Falamos de um tempo em que as coisas mudavam de forma sob outras circunstâncias.

É desse tempo que vem Makunaima.

Aliás, ele vem de um tempo anterior.

Passar pela necessidade de uma forma humana ocidentalizada, concreta e masculina já podem ser efeitos claros da colonização.

Ao mesmo tempo em que a imagem sugere a ação de integrar, harmonizar, o excesso de elementos fundantes também pode sugerir um desagregar, um expandir, um desintegrar. 


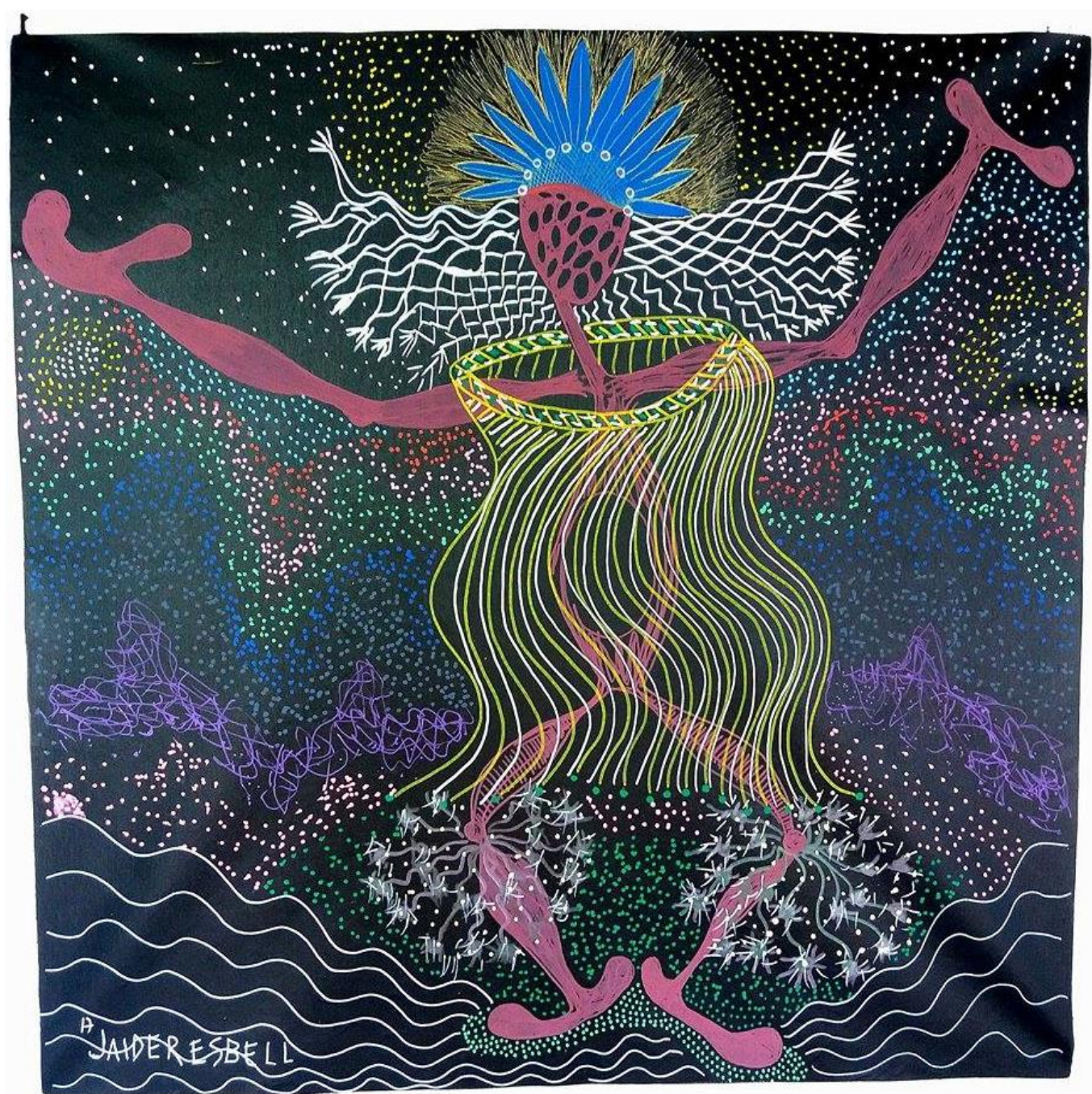

Makunaima - II. Técnica: acrílica e pincel posca sobre tela. Tamanho 90 x $90 \mathrm{~cm}$. Ano 2017 .

Makunaima em aspectos humanos.

O mito aparece aqui sugerindo uma condição de plenitude.

É possível vê-lo como um ser masculino e imponente.

Ele parece seguro em sua figura que agora existe; tem movimento e luz chamativa.

Parece absoluto como se fosse o próprio encantamento tomando forma para atender visualidades.

Eis um importante ponto a ser tocado. 
Em matéria de arte indígena, não algo externo, europeu ou emoldurado, carecemos, nós artistas, de algo dinâmico (agência?) para que se alcance a condição exata de transpor e fazer transpor mundos.

Não deixamos de buscar o efeito contrário quando simplificamos a imagem do mito essencialmente fluido para algo limitado a uma imagem.

O sentido limitador que é ver-se humano, mortal, material.

A materialização de Makunaima em uma figura emoldurável pode ser uma forma de puxar um fator complicador.

Assim quem sabe temos as bases ou as pistas para a sua devolução a um estado anterior, o estado que se espera, o estado pleno da arte, o estado de energia, quando a visão vê o que é abstrato, pois aí é onde reside o todo sentido. 


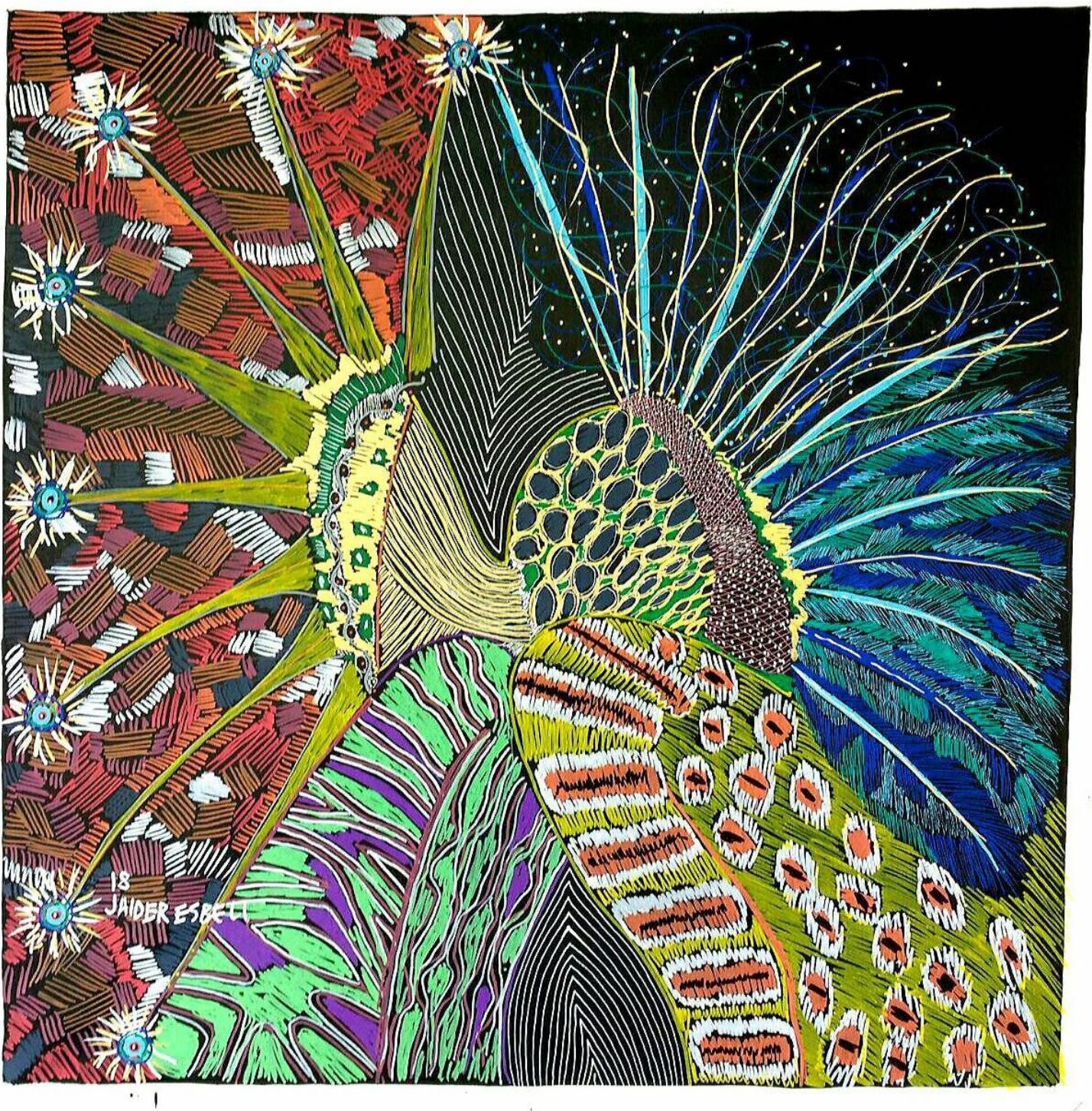

Makunaima - III. Técnica: acrílica e pincel posca sobre tela. Tamanho 90 x 90 cm. Ano 2018.

O exercício de desconstruir a imagem estatizada de Makunaima exige de mim, especialmente, um esforço extra e muita habilidade na construção da imagem da nossa relação.

Lembro que sobre meu avô Makunaima e sobre eu mesmo pairam interpretações além de nosso alcance.

Por diversas razões não vamos alimentá-las pois temos um norte para onde rumar. 
As obras desta coleção (15 telas apenas) nunca serão suficientes para contemplar esse universo imagético.

Assim, sem muita cerimônia, convidamos nosso interlocutor a passear sem reservas pelo mundo da subjetividade e esperar ainda mais um tempo.

Aparentemente, Makunaima é algo indefinido nessa imagem embora em alguns pontos de minha aparição eu tenha dito e escrito que a imagem é parte da arte de mostrar o momento transitório continuum das coisas.

Esta jornada poética com meu avô só tem oxigênio e solo nesse ambiente.

Uma boa dose de criatividade imaginativa é preciso.

Assim como a imagem é desfeita, espera-se seu efeito decodificador em nossa mente decante e o que outro se encante em continuidade. 


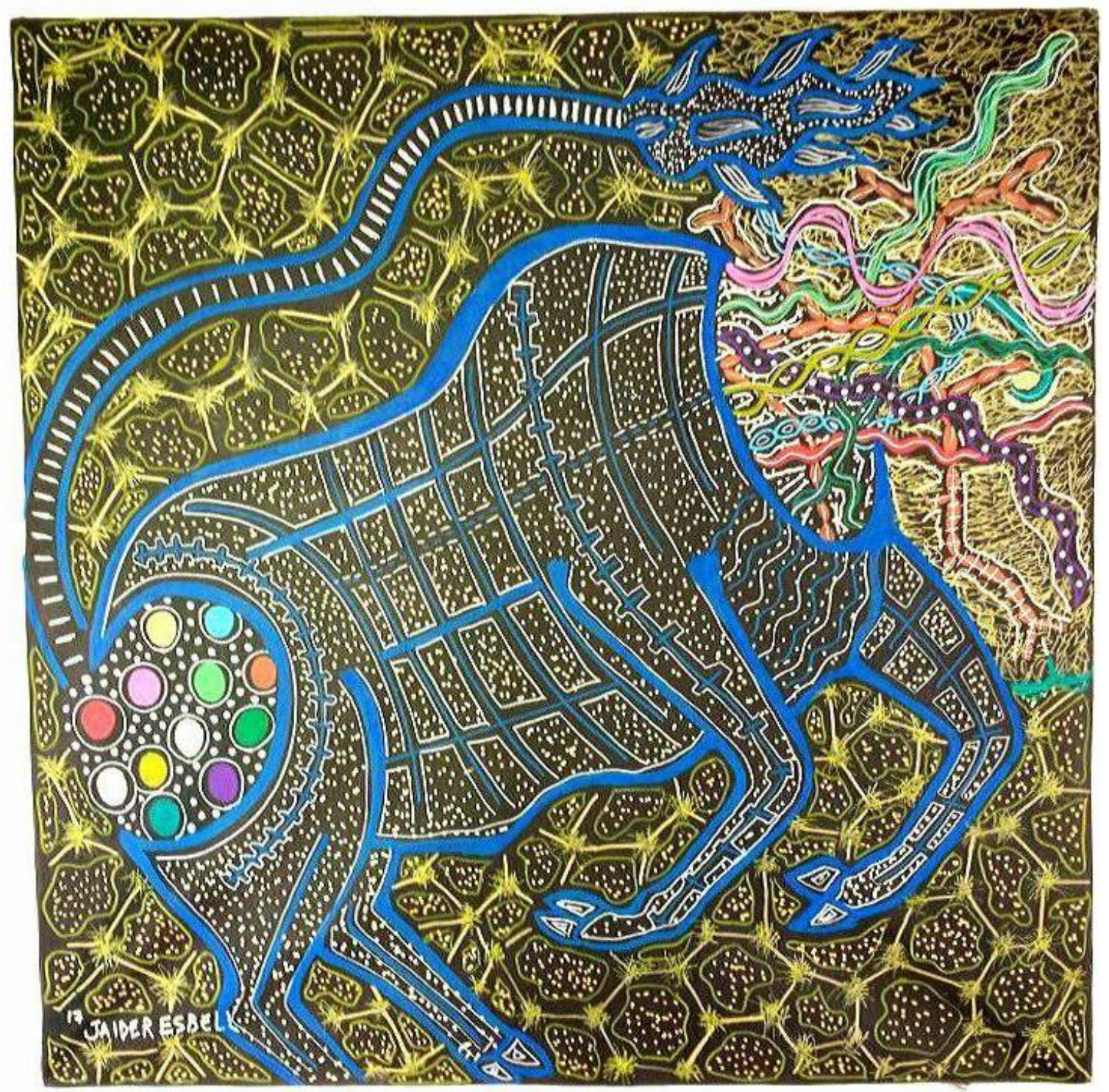

Makunaima - IV. Técnica: acrílica e pincel posca sobre tela. Tamanho 90 x 90 cm. Ano 2017.

Não é objetivo meu, em vida, medir o tamanho do meu avô, ou a sua pequenez.

Não é objeto de nossa vida-estudo confrontar as energias liberadas a partir de suas exposições anteriores.

A imagem acima tende a levar o interlocutor ao lado pouco conhecido da atuação de Makunaima, as visões estratégicas.

Ele foi um visionário? 
Devo fazer essa pergunta usando o tempo passado do verbo ser?

Quase instantaneamente as pessoas que olham essa imagem ariscam que seja a mula sem cabeça.

Personagem do folclore nacional, a mula sem cabeça está diretamente relacionada com o cristianismo.

Pois dizem que a mula sem cabeça é algo que surge quando um padre e uma fiel fazem fornicação dentro da igreja.

Não aqui. Aqui não temos uma mula. Aqui temos um espécime de gado bovino. $\mathrm{O}$ mesmo gado bovino que hoje adentra a floresta amazônica destruindo tudo. O mesmo gado bovino que antes dessa onda colonizadora não existia ainda por aqui.

Makunaima em uma de suas passagens cria um boi a partir de uma pedra branca no meio do campo.

Makunaima criou um boi antes dessa colônia se estabelecer, o que pode significar isto? 


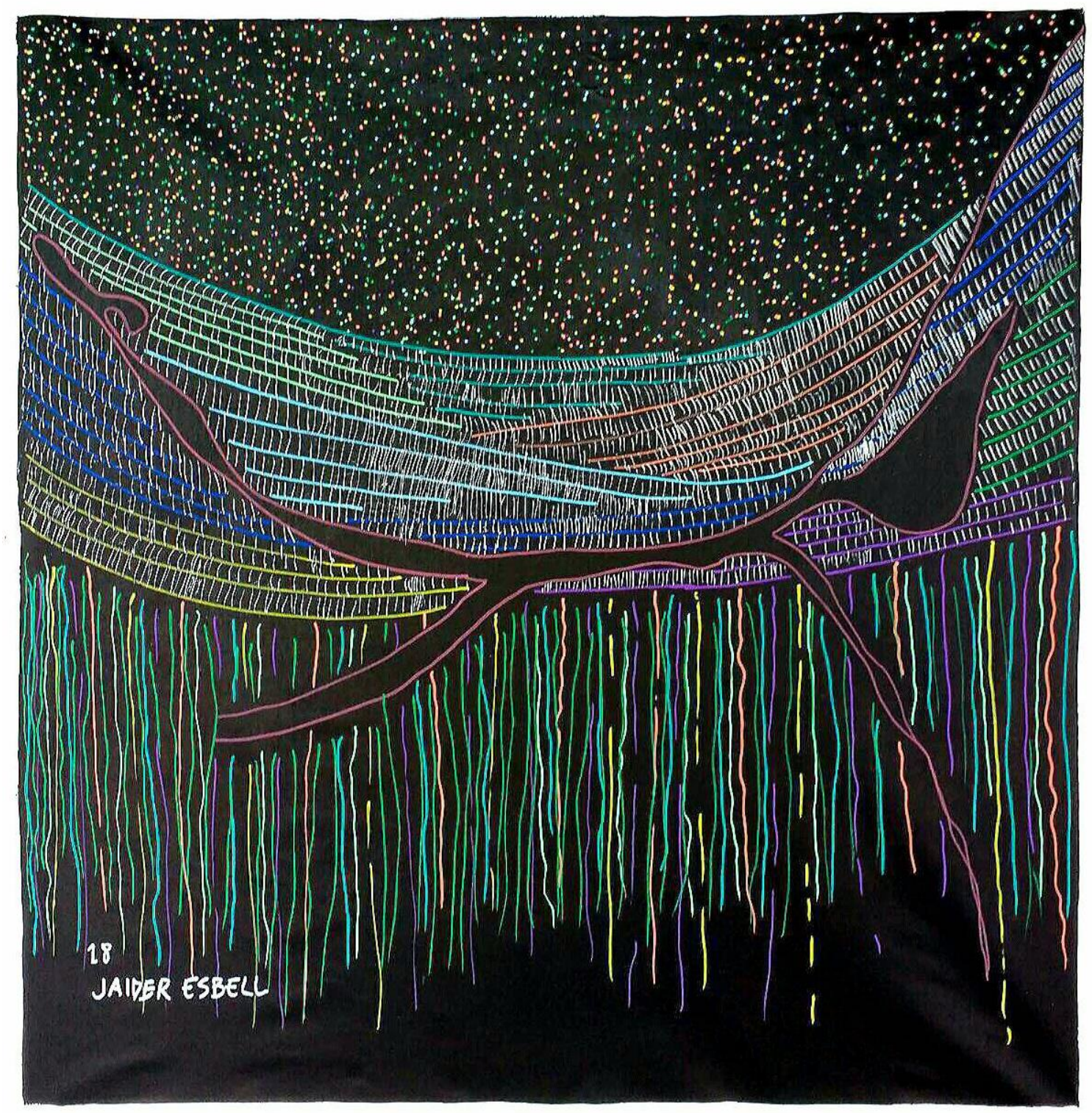

Makunaima - V. Técnica: acrílica e pincel posca sobre tela. Tamanho 90 x $90 \mathrm{~cm}$. Ano 2018.

Makunaima para muitos é um mero índio e aqui dorme na rede em um lugar inexistente. Para outros apenas uma invenção da literatura, algo em desuso, portanto desnecessário.

Supomos que para muitas pessoas as palavras Makunaima ou Makunaíma são, ainda, completamente novidades. Em duas frentes diretas pontuamos nossos esforços.

A parte que acredita que Makunaíma tem mesmo caráter nenhum, está fora de moda, mas bem representa o Brasil preguiçoso de gente com índole duvidosa. 
A parte que escuta ou lê sobre o mito Makunaima pela primeira vez são objetos diretos de nossa agência.

Ao eleger tais linhas de ação outra agência é demandada, a contextualização.

Assim como o termo decolonização tem seus resistentes, o termo índio aparece com uso deslocado já por consenso entre as partes que representam o movimento ou os movimentos indígenas.

A preguiça e a improdutividade atribuída ao índio - leia-se e fale-se indígena tem seu peso negativo reforçado com o desconhecimento mínimo do status quo como nascer, viver e trabalhar na floresta.

Falo aqui em pré-conceito? 


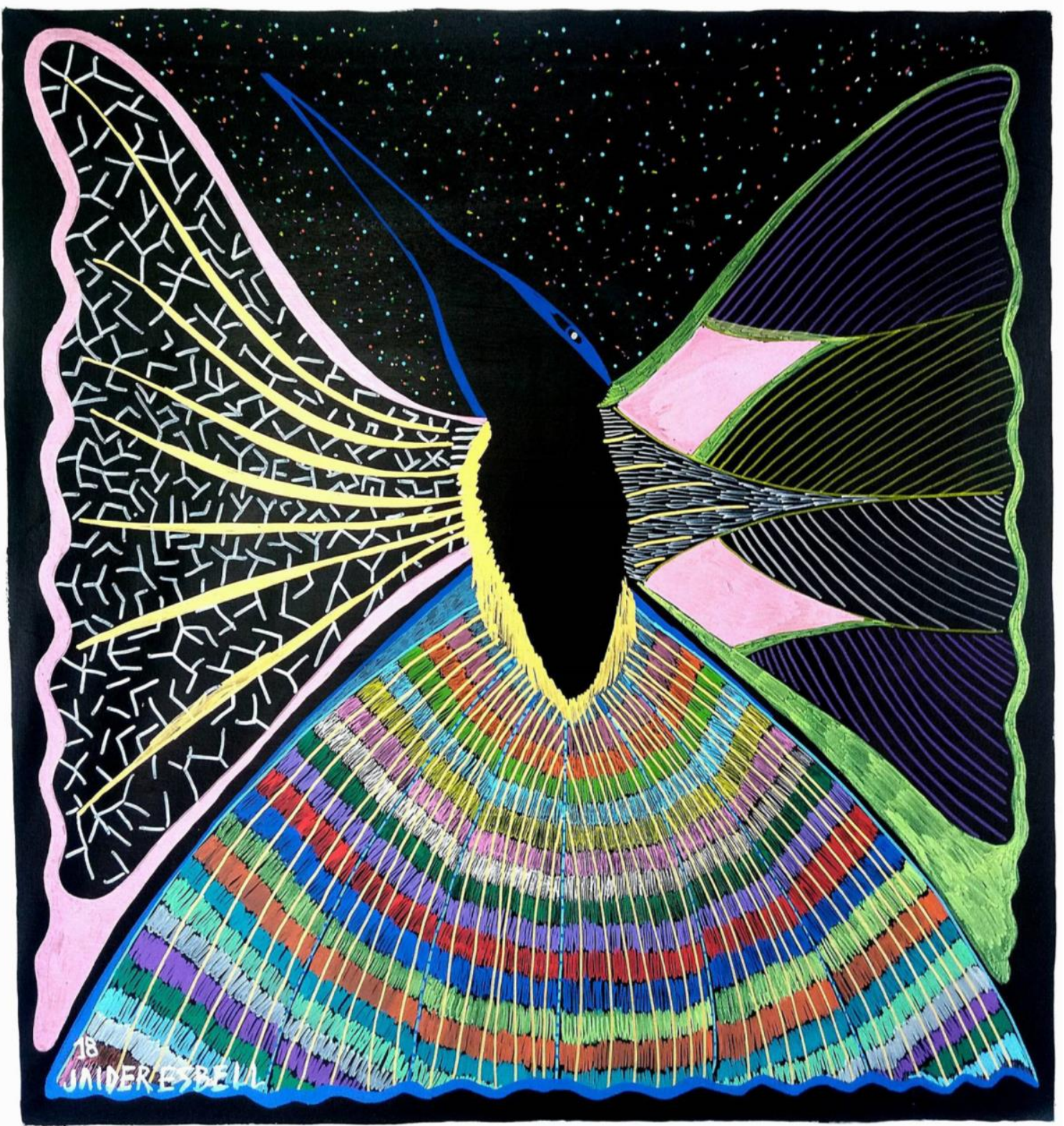

Makunaima - VI. Técnica: acrílica e pincel posca sobre tela. Tamanho 90 x 90 cm. Ano 2018.

Makunaima agora é um beija-flor, ei-lo. É assim que ele também se apresenta. Exatamente neste ponto guardo grande entusiasmo.

A prontidão instantânea de Makunaima transformar as coisas e transmutar a si próprio são o lado mais fantástico, portanto o menos alcançado e menos compreendido de seus grandes feitos. 
A transformação, a mudança de estados, e como disse antes, questões sobre gênero também são perfeitamente plausíveis de se achar no cômputo do passar fluido e imprevisível que agora me faço parte, em parte.

Temos no texto alguns pontos relevantes que devem ser tratados com mais recursos no decorrer de nossa exposição conjunta, no por vir.

A publicação oficial deste ensaio em um periódico bem como a exposição de arte Meu Avô Makunaima em um salão colonial numa metrópole amazônica são factuais.

Este texto tem o mesmo contexto; ocupar espaços diversos com o que há de novo ou que não tenha sido bem aproveitado quando das primeiras investidas, no mínimo curiosas e bem intencionadas, sobre o universo incomum de meu avô Makunaima pelos pesquisadores anteriores. 


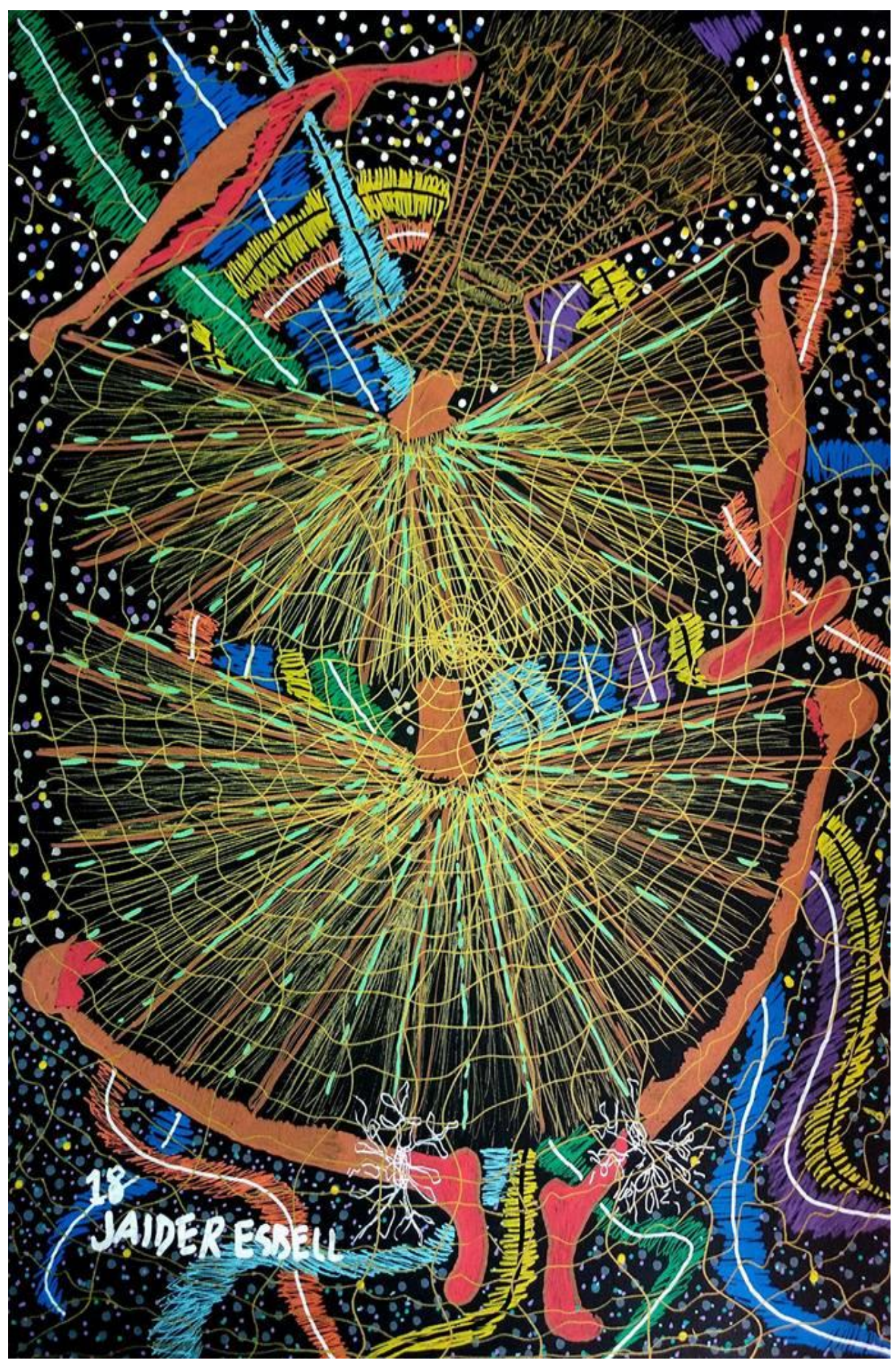

Makunaima - VII. Técnica: pincel posca sobre papel canson. Tamanho 29,7 x $42 \mathrm{~cm}$. Ano 2018. 
Há uma festa sempre acontecendo no universo indígena?

Foi o que transpareceu Makunaíma e assim foi julgado vulgar, desrespeitoso e inconsequente por natureza?

Talvez a alegria dos indígenas, a ideia de felicidade que o externo tanto almeja, seja uma das causas adversas para levianas imposições.

A alegria farta, a farta ou sutil indumentária que os fazem únicos, foi o que os faz ameaçados, talvez.

Nessa legenda busco ver a imagem de Makunaima também nos raptos seculares e cotidianos que nunca cessam.

Nesse recorte cabe promover tais questões.

Aqui se pode puxar o fato testemunho e devolver o exotismo a quem ainda confunde os dessa terra.

Todas as referências aplicadas na leitura e feitura de Makunaíma para o grande público além floresta são exóticas.

Neste quase um século de máxima exposição o que ainda é possível falar sobre meu avô?

Defendo que tudo o que nunca foi dito.

Nunca foi dito exatamente por não haver o que dizer.

Era de um herói que o povo precisava?

Foi mais divertido pô-lo vilão para vendê-lo mais caro vide a extensa ficha de delitos do sujeito. 


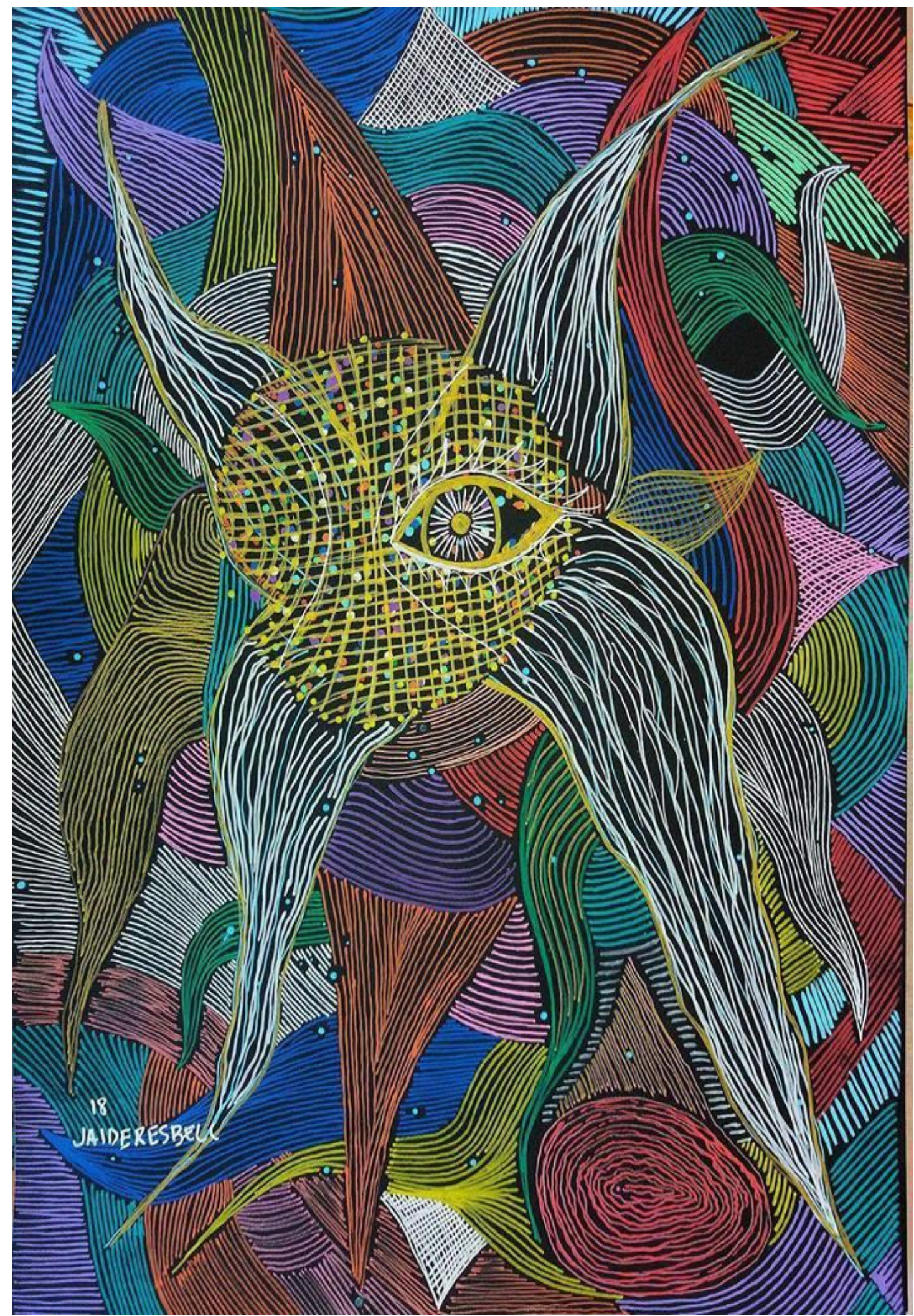

Makunaima - VIII. Técnica: acrílica e pincel posca sobre tela. Tamanho 90 x 90 cm. Ano 2018. A obra original pertence ao acervo de Ninfa Parreiras. 
As linhas gerais de Makunaima devem, em alguns momentos, desalinhar Makunaíma para compor com tantas outras o Makunaimî (como se grafa na língua Makuxi).

Os detalhes substanciais dessa agência estão em publicar este texto como conviteprovocação na condição de neto direto da entidade.

Seria um risco se de fato estivéssemos pleiteando compreensão.

Arriscado seria amargar a incompreensão de algo tão íntimo e particular como as relações familiares.

Mas não é só disso que tratamos.

Não é a busca por algo confortável e alentador o que almejamos.

Também não vamos falar em (in)justiça ou reparação visto que em arte geralmente não há espaço para certos ou errados, bonitos ou esteticamente desqualificável.

Deixo saber o tamanho grandioso do nosso bem estar em viver tal protagonismo.

Não é uma tentativa audaciosa de reescrever a história.

Não é ainda nada relacionado com uso estratégico de mídia ou furos de ineditismo.

Nada tem a ver com usar e ser usado.

O sentido está em acharmos um veio fértil para que o lado morto do mito surja vivo como algo testemunhal e não mais como antes fora feito.

Vamos em desalinho ponto por ponto até que isso mostre-se pleno. 


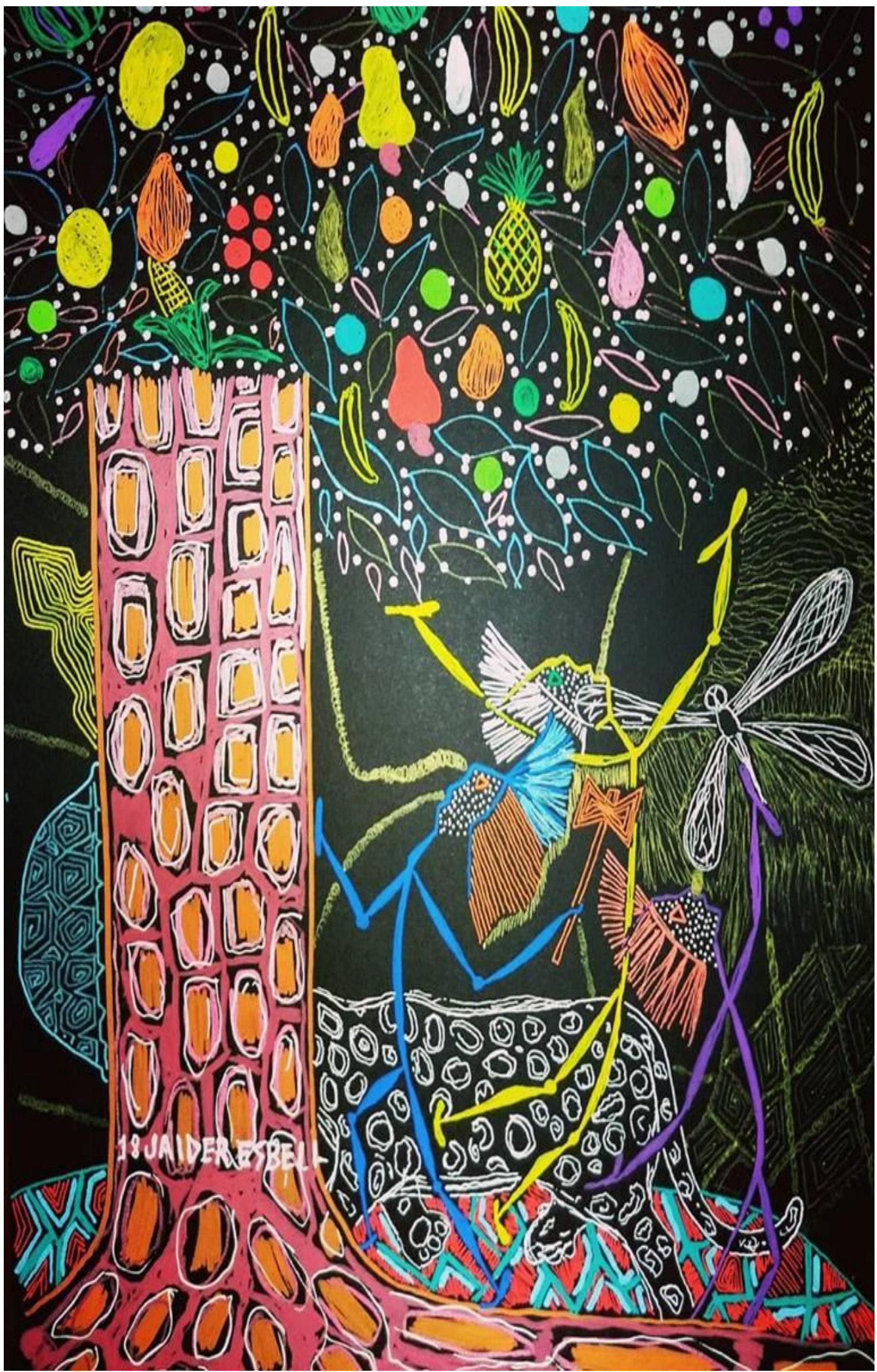

Makunaima - IX. Técnica: pincel posca sobre papel canson. Tamanho 29,7 x 42 cm. Ano 2018. 
Não há uma sequência lógica de eventos para algo tão fluido como a existência de Makunaima.

De fato não há como lhe atribuir uma biografia ou uma historiografia.

Nesta obra aparecem ao menos mais dois personagens que posso dizer que são equivalentes ao mito famoso.

A percepção para os personagens na arte pode ser de uma composição aleatória, caso não haja contexto.

Eu que tomo parte nesta genética amplio neste sentido minha exposição ao todo no mesmo tempo em que busco estar na área externa a este momento.

Isso é um exercício meu.

O momento crucial do corte da grande árvore Wazak’á pode dizer muito caso consigamos deixar que seja dito.

Me faço valer de colocação em momento anterior sobre as pontas soltas dos fios condutores para de fato nada concluir.

A ideia de uma divindade monoteísta tem relação com o isolamento de Makunaima, o personagem Makunaíma, em detrimento de Anik'ê e Insikiran seus irmãos inseparáveis, na capa do livro.

O corte da grande árvore é simbólico por razões ainda não vistas ou mostradas.

Como a valia de que há nesse ato-decisão um ato seguinte nos faz pensar com bastante conforto sobre uma projeção da vida sobre seus próprios limites a uma outra dimensão. 


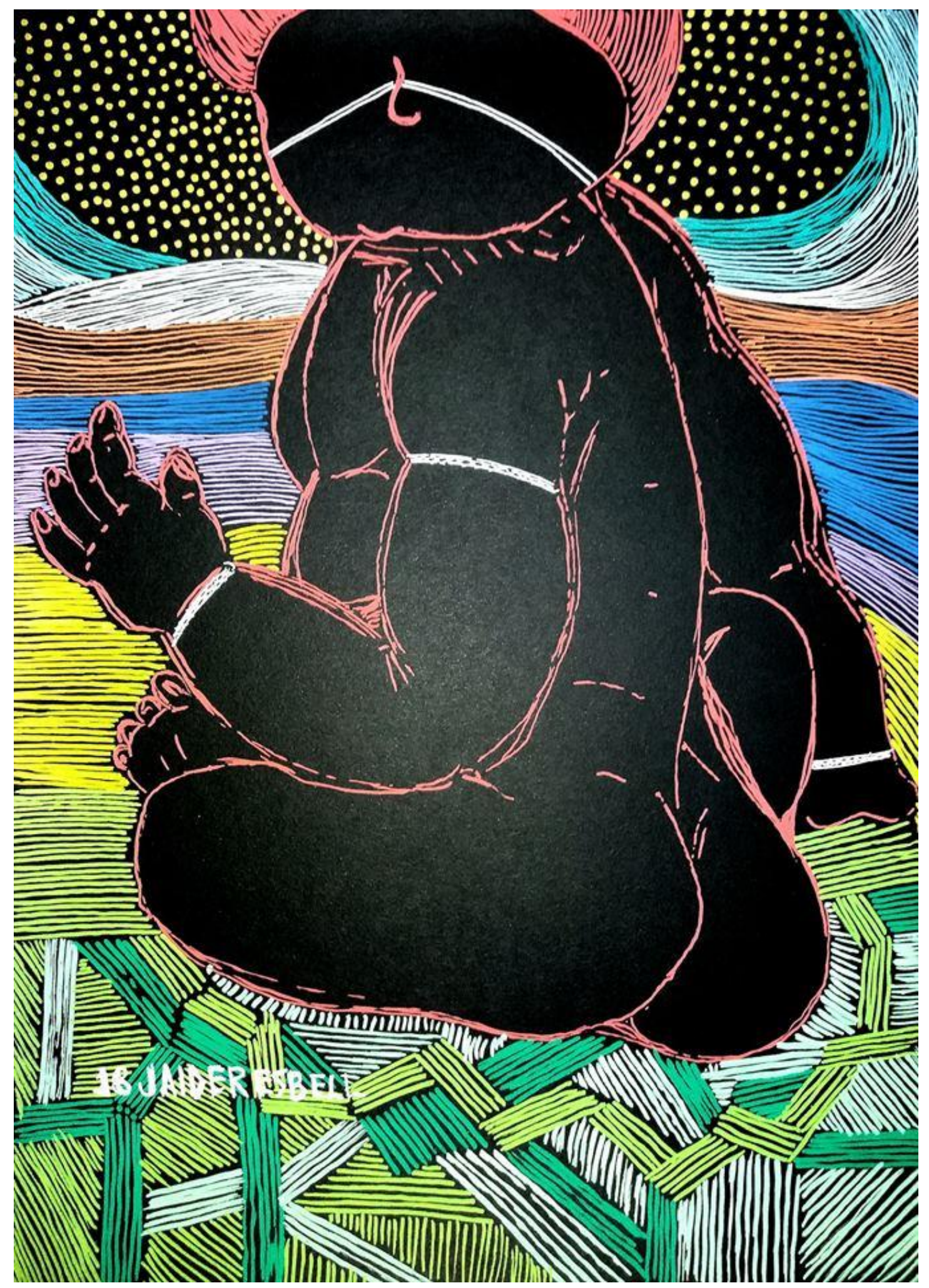

Makunaima - X. Técnica: pincel posca sobre tela. Tamanho 29,7 x 42 cm. Ano 2018. 
Uma criança que ainda mama no peito é como Makunaima aparece em algumas cenas. Em outros momentos ele aparece forte e violento.

Todas essas aparições nos convidam a pensar os extremos nas coisas impossíveis, fora de qualquer lógica razoável para o mundo normal.

Como pode alguém ou algo tão forte e poderoso como Makunaima se deixar parecer tão frágil e vulnerável como um bebê de colo?

Tais questões aparecem tão fora de qualquer sentido como a tal reinvindicação de parentesco direto a que me lanço e faço saber oficialmente (?).

Eis portanto o componente mais instigante nos fazeres ou afazeres de Makunaima.

Como isso pode acontecer dessa maneira?

Assumir tais disparidades não lhe é um problema.

O problema, se há algum, pode estar, como disse, no verdadeiro ente exótico, o externo, o ocidental, o estranho.

Tal como adiantei, a composição deste texto no formato de publicação como ciência é um caminho para atender demandas específicas da arte indígena contemporânea a partir de uma agência maior em abordar todas as questões relacionadas direta e indiretamente com a cena Brasil da atualidade.

Rompe alguma coisa esse romper? 